\title{
The Arab Spring Crisis and the Democratic Trend in Jordan
}

\author{
Fawzi Ahmad Tayem ${ }^{1}$, Radwan Mahmoud Al-Majali ${ }^{1} \&$ Saddah Ahmad Al-Habashnah ${ }^{1}$ \\ ${ }^{1}$ Department of Political Science, Mu'tah University, Jordan \\ Correspondence: Fawzi Ahmad Tayem, Department of Political Science, Mu'tah University, Jordan. E-mail: \\ Ibrahim_hasanat@hotmail.com
}

Received: May 19, 2018

doi:10.5539/jpl.v11n3p98
Accepted: June 25, $2018 \quad$ Online Published: August 30, 2018

URL: https://doi.org/10.5539/jpl.v11n3p98

\begin{abstract}
The study aims at pin-pointing the effect of the Arab Spring as one of the external factors, that affected the Jordanian political regime during the period(2011-2017) at the different political, economic, security and social levels and concentrate on its effect on the democratic structure in Jordan, and how to reinforce indicators of democratic trend in Jordan. Where the study refuged to use the method of analyzing systems to test the main hypothesis of study in considering the external factor play an effective role either negative, or positive in enhancing indicators of the state democratic trend.

The study deduced a result states that the Arab Spring formed a positive and negative factor in the democratic trend in Jordan, from part of the influence of the political instability in reinforcing the political will for the Jordanian decision-maker in the dedication of reform indicators and democratic trend, and in return the precariousness's of the Arab Spring formed a negative factor in increasing problems of the political, economic, and social structures, the thing that formed an obstacle in front of reform and democratic trend. Also the study recommended with the necessity of concern about the other indicators and reinforcing the effectiveness of associations of the civil community, and respect of human rights, the economic development, the political and social stability, and culture and democratic practice.
\end{abstract}

Keywords: The Arab Spring, Jordan, democracy, democratic trend

\section{Introduction}

The external variable formed one of the effective factors in the environment of the Jordanian political since the day of founding the Hashemite Kingdom of Jordan in 1946 till the present time, where this effective role had an effect in occurring changes in the political and economical structures, shared in influencing the trends of the political decision-maker towards development and modernization, where the democratic trend was from those alternatives that achieved positive indicators in some sides, and the state of inactivity and weakness in other indicators, where the effect of the external and internal factors had the great role in defense, or weakening the track of the democratic trend in Jordan at historical stages of the development of the Jordanian political regime.

Jordan witnessed the first true form of the parliamentary governments headed by Suleiman Al-Nabulsi in 1956. It did not last long because of the regional and international circumstances that affected the track of democratic development in Jordan at the parliamentary, factional and legislative level, for it had led to the absence and instability of the parliamentary regime till the year 1989 .

From other part it appears to the follower of the economic reforms track in Jordan that they were a part of the effects to which Jordan is exposed from its external environment, either from demands of the international financial foundations, and the state of regional instability, the thing that it is negatively reflected in achieving a state of unfitness with the nature of the internal environment, so it commences with it the internal role of state in retreat on the expense of its external concerns, and so rise with it internal disorders, lead to a state of instability expressed through disturbances and popular protests. This is what greatly happened in the popular protests in the year 1989, 1996, 2009, and 2011. Corresponding to that we notice that political reforms appeared in Jordan as a part of popular pressures to which the regime is exposed in its internal environment, that rise in the shadow of the state of crises, protests, and internal demonstrations; because of the negative results out-coming of the economic reforms, and appears the response of the regime to the popular demands through creating internal 
connections in its relationship with all parts of the community, and this matter had been expressed in two cases ${ }^{1}$.

The first case: failure of most of the economic reforms results done by Jordan at the fabulous eighties period which its application terminated with an economic crisis, its evident negative effects on citizens had the motive in rising a state of disorders and protests in 1989. The matter that increased pressures on the political authority, pushed the late King Al-Hussein Bin Talal to commence the stage of the political reforms. But the state of regional instability led to retreat of the political reforms in Jordan after the year 1991; in return, Jordan returned to follow economic policies, the thing that raised with it a state of great change in Jordan. They were not of positive results in their political and economic side, and the started about the absence of the social of the state.

and economic side, and the started about the absence of the social role of the state.

The second case: the delay and failure of policies of trade release and openness done by Jordan in the period of nineties, and the first decade of the twenty first century in achieving positive results at the economic level, formed a great push in raising numerous misshapes and disorders inside the community; corresponding increase the state of regional instability by the rise of a wave of the Arab Spring and crises of the Arab region in the year 2011 push to increase pressure and demands on the regime, the thing that led to the start of another stage of political reforms, and King Abdullah, the Second Ibn Al-Hussein did change four governments through a period of a year and a half, and his call to review the legislations and rules organizing the political life and doing amendments in the constitution. Start of dialogue stage with factions and political powers.

\subsection{Problem of Study}

The effect of the external variable forms one of the effective factors in the political regimes, the matter that may occur influence with it in the trends of the states towards democracy, that appears within two levels:

The first level: a case of response to requirements of the international environment and case of adaptation, the matter that pushes the decision-maker to do a group of legislative and institutional procedures that achieve indicators of democratic development.

The second level: a case of political instability, leads to increase of political and economic problems on the rest of subsidiary systems inside the politicalregime, the matter that leads to not achieving indicators of democratic change.

From this point the start of the period of the Arab Spring in year 2011 formed on effective external factor in the trends of the Jordanian politics in achieving the economic and political reform, the matter upon which many sides that affected in the political and economic structures of the Jordanian political regime resulted during the period(2011-2017).

From here rises from the problem of study an essential question and a group of subsidiary questions: The main question: to what extent could the Arab Spring affect the trends of Jordan towards democracy?

\subsection{Subsidiary Questions}

What are the levels of political reform in Jordan?What are the most important steps and indicators of trending towards democracy in Jordan during the period of the Arab Spring (2011-2017)?

\subsection{Objectives of Study}

The study seeks to achieve the following objectives:

1) Pin-pointing the core of democracy and the most important indicators of democratic change.

2) Recognizing the environment of the Jordanian political regime, level of democracy in Jordan, and the most important sides of political and economic reforms.

3) Recognizing the most important effects of the Arab Spring on Jordan, and the most important steps of Jordan in trending towards democracy through the period (2011-2017).

\subsection{Significance of Study}

The significance of study comes through the scientific concerns with the special studies in affecting the regional variables in the political regimes, and studying the nature of those political regimes and the most important levels and indicators of the democratic development in them, where the study forms a significance for getting aware and studying levels of response to influences of external and internal variables in the process of

\footnotetext{
${ }^{1}$ Al-Majali, Radwan (2005). The Political \& Economical Reform in Jordan between Theory and Application, Journal of Education, Al-Azhar University, Cairo, No.162, November.
} 
decision-making inside the political regime and their reflections on levels of political stability and the democratic trend.

\subsection{Limits of Study}

- Time limit: the study covers the period extending from (2011-2017), where it witnessed the start of the Arab Spring till the period of preparing the study.

Place limit: the Hashemite Kingdom of Jordan.

Qualitative domain: studying the Jordanian political regime.

\subsection{Hypothesis of Study}

The study starts from a hypothesis discussing the relationship between a subordinate variable and an independent variable:

The external factor plays an effective role in the democratic trend of the political regime positively or negatively.

- There is a relationship between the effect of the external factor on the democratic trend through two levels:

The first level: the external factor achieves a positive role in the motivation towards adopting the political regime to the steps of the democratic trend.

The second level: the external factor achieves a negative role in increasing the state of instability in the political regime, and in littling opportunities of trend towards the democracy.

\section{Methodology of Study}

This study depends on the method of analyzing the systems in studying the political regime. That is through concentration on the model(David Easton) for the political regime, and effects of the external environment on the political regime, and in particular influence of the Arab Spring on processes of the regime through rising the state of the regional instability and what resulted in from the wave of protests in the Arab region, that pushed to forming the movements of protesting in Jordan in 2011, formed pressure pushed by introducing a group of different demands and specified the pattern of the government response on the form of decisions, policies and issuing legislations and laws to take them and form an important side in recognizing steps and levels of democratic trend in Jordan during the period (2011-2017).

\subsection{Concepts of Study}

The Arab Spring: The concept of the Arab Spring, or the Arab Revolutions, or Revolutions of the Arab Spring "viewed that peaceful protesting movements started in the different Arab states since the endings of the year 2010 and the beginning of 2011 call for changing the political regimes, and achieve the economic reforms at different quarters of life".

"The Arab Spring" is a great historical turning point witnessed by the Arab region starting from Tunisia, the Egypt, Lybia, Yemen and Syria, then different Arab States were affected at variant degrees, resulted in economic and political conditions different from their precedent states, and appearance of the state of disorder, previously called in accordance with American predictions introduced by the former American Minister of Foreign Affairs, Condaleza, Rais and called it "the Creative Disorder".

The Political Regime: (David Easton) defines it "as a group of interwieven and connected elements, related with authoritative distribution ofvalues in the community", where the political regime is tightly connected with the economic system, and the social system at any community, study of political regime cannot be done in seclusion of other societalsystems study ${ }^{(3)}$, analysis of political issues is connected with the extent of the ability to understand characteristics and basics of the political regime and authority, and depend the economic and uneconomic factors (cultural, dogmatic, educational and legal, etc...), so keeping authority is the essence of the government operations, and it is how the state practice the government or governing?, and the nature of authority and nature of the political regime in the state, they both reflect the fact of difference in the nature and weights of powers, and the different social groups from which it consists ${ }^{4}$.

Democracy: the word democracy is derived from two Greek words, they are: (Demos) means the people and the word (Cratia) means (the government or 'authority'), and so Democracy linguisticallymeans 'the government of

\footnotetext{
${ }^{2}$ Kamseis, Kalidah (2014). The Arab Spring Between Revolution \& disorder, Journal of Arab Future, Arab Unity Studies Center, Beirut, No. 421, PP.220-225.

3 Al-Munoofi, Kamal(1987), Fundamentals of Comparative political systems, Rbeian Co, Kuwait P.44.

${ }^{4}$ Dafi', Hasan (2007), Principles of Politics, Ashroog International. Library, Cairo, P.192.
} 
the people', for this, this nomination concerns governments elected and selected by the people. But "Democracy" with its comprehensive concept idiomatically means "the government that decides sovereignty of the people", and guarantees freedom, and political equality among all individuals of the community, in order the authority subdues to the control of the people, within sovereignty and respect of the law". And Philip Shometer defines democracy that it is "taking the institutional precautions for the sake of obtaining the political readings, through which individuals acquire decision-making by votes competition".

\subsection{Previous Studies}

1) (Al-Majali, 2015) study: "Political and Economic Reform in Jordan between Theory and Application", this study discusses research in the most important steps of reform in Jordan at the political and economic level through the period extended from (2011-2015), and in influences of internal and external environment in the reform process, in the indication to the most important indicators of democratic trend during that period, and what occurred of changes at the level of political, economic and legislative structures. The study assured that there are true influences of the internal and external factor in pushing towards the political reform in Jordan at a great form through that period.

2) (Abul hasan Omer, 2014) study: "Future of the Track of Democratic Conversion in states of the Arab Spring and its Problematics in the Shadow of the Present Changes",it is a research study covered submitting a vision about the concept of democratic conversion and its relationship with the other concepts, like the democratic transferrance, democratic stabilization, and the political reform, then discussed indicators of democratic conversion, its causes and the external factors affecting them. Talk about problematics of democratic conversion in the statesof Arab Spring (terrorism, extremism, state of political instability, absences of dialogue and nationalagreement, weakness of institutions and deterioration of economic condition. The study deduced results, the most important of them existence of many obstacles of the democratic conversion in the states of the Arab Spring, connected with the political, economic, and Social structures, did not achieve a true democratic conversion, in addition to loss of the political stability, corresponding existence of interventions of powers, and the international effectives affecting that.

3) (Mohammad, 2013) study: "internal and external challenges affecting the Jordan national security in the period of (1999-2013), a case study. The study aimed at analyzing and studying the nature of internal and external challenges that affect the Jordan national security, and shedding light on the administration of the Jordanian State and its competence to deal with these challenges.

The study employed the method of descriptive analysis and the historical method in treating the subject of study. The study had deduced a group of results, the most important of them is: that the Jordanian state faces the precariousness's of instability influence in the region; the thing that negatively shared in influencing the Jordan national security. The state of the Arab Israeli conflict, then the American occupation of Iraq and the Arab revolts are the most important challenges that face the political stability and Jordan national security.

(Al-Sawadhah, 2016) study: effect of regional changes on the political stability in Jordan (2011-2016). The study tackled, and it is a university dissertation the influence of the external factors during the period of study. Particularly the Arab Spring on Jordan from part of political stability political and economic reforms, where it covered studying the political regime, departments of decision-making, and levels of political reforms at the period, before and after the Arab Spring. And then the study deduced that factors and external changes played an effective role in the process of stability and the democratic trend in Jordan, together with agreement with influences of the internal environment.

\subsection{Firstly: Theoretical Framework of Study}

It is viewed of the concept of democratic conversion in the context of a group of the synonymous concepts to the like the democratic transference or (Democratization), or states moving towards democracy (democracy trend). It is an issue with concerns in politics since the second half of the twentieth century seventies. And at the extent of the threepast decades a great deal of books, studies and reports that discussed this issue at different levels appeared: theoretical and applied, quantitative and qualitative, case studies and comparative studies. Literatures of "Democratic conversion" raised many concepts, theoretical statements and the methodological and analytical inlets to comparison of this phenomenon. Also concerned about examining, and discussinga large group of issues

\footnotetext{
${ }_{5}^{5}$ Abu A'mood, Mohammad (2009). Democratic Conversion \& its Problematics in Arab Countries, Democracy Journal, $1^{\text {st }}$. January, from Al-Ahram E. site http://digital.Alahram.org.eg/articles.aspx
} 
and related variables with the process of transference either from part of its inlets (causes), orpatterns (ways of transference), or outlets (nature political systems in the stage of after the transference) ${ }^{6}$.

In the context itself many studies indicate about the factors that motivate the trend towards democracy, that had been divided within three waves to covert towards democracy: ${ }^{7}$

- Studies of the first wave that indicated that the democratic transference factors after the First World War: economic development, urbanite conversion and appearance of the bourgeois class and the middle.

- Studies of the second wave that indicted to the military factors and influence of the victorious states in the Second world War on the states that occupied them, and affecting the colonizing states by the western powers, that adopted the democratic regime.

- Studies of the third wave, where Samwel Hintington to the influence of a group of internal factors related with the state or the group of states.

From here appears influence of a group of the internal and external factors that share in the trend and transference to democracy"

Internal factors: the true will of the political leadership, or the political authority (example: the democratic conversion in Spain in Khowan Karlos's reign after the year 1982), and deterioration of the legitimacy of the political regimes, the undemocratic (e.g. the democratic conversion in Tunisia after the year 2011), the economic factor: achieving the economic development may lead to trend towards democracy (e.g. democratic conversion in South Korea and Malizia), and failure of economic development may lead to search for democracy as a choice to achieving the first case (case of Jordan after the economic crisis in 1989) ${ }^{9}$, also increasing the effectiveness of the civil community leads to democracy, in addition to increasing the political culture and the popular awareness.

External Factors: Represent the external pressures of the giving international powers and the worldly trend economic institutions (Mexico, Greece as model), towards democracy (transference of Portugal to democracy after the government of Salzar in 1975-led to Worldly wave after that period, transferred thirty states to democracy), and the Demono theory (the democratic conversion in a certain state encourages democratic conversion for other states), this is what prevailed in the Arab Spring wealth and popular demands in transferring to democracy ${ }^{10}$.

Also there is a group of indicators share in reinforcing the democratic conversion in the states ${ }^{11}$ : as the state of law and institutions, will and political leadership, the political multitude, political partnership, peaceful exchange of power, respect of human rights, effectiveness of institutions of the civil community, economic development, political and social stability and culture and democratic practice (see table 1).

\footnotetext{
6 Ibrahim, Hasanein (2013). Democratic Transference in the Arab World, Al-Dawha, Al-Jazeera Center for Studies,Febr.14 $\mathrm{http} / /$ studies.aljazeera.net/files/Arab world democracy.

7 Ahmad, Ieman(2016). Democracy \& Democratic conversion, the Egyptian Institute for political \& strategic studies, Cairo,p.1.

${ }^{8}$ Ahmad, Ieman (2016), Ibid, pp. 2-3.

${ }^{9}$ Al Majali, Radwan (2014), Ibid, pp. 200-201.

${ }^{10}$ Al Majali, Radwan (2014), Ibid, p. 212.

${ }^{11}$ Al-Salek, Deedi (2008) the Democracy Practice is an entrance to persistent Arab development, Journal of Arab Future, No. 356, October, Beirut center for Arab Unity studies, pp. 28-31.
} 
Table 1. The most important indicators and different models in the democratic conversion ${ }^{12}$

\begin{tabular}{|c|c|}
\hline Indicator & The Model \\
\hline The constitution & $\begin{array}{l}\text { Role of the new constitution in South Africa after termination of the old constitution in } \\
\text { the stage of racial discrimination separation, for the new constitution covered all } \\
\text { political \& different social streams \& aspirations. }\end{array}$ \\
\hline $\begin{array}{l}\text { National Unity and } \\
\text { State of Agreement }\end{array}$ & $\begin{array}{l}\text { Existence of popular unanimity among classes of the community about the necessity of } \\
\text { living in the shadow of a democratic regime including the opposers of democratic } \\
\text { regime, the thing that led to democratic conversion as the case of Argantina. }\end{array}$ \\
\hline $\begin{array}{l}\text { Political participation } \\
\& \text { Fairness of the } \\
\text { Elective Process }\end{array}$ & $\begin{array}{l}\text { Many states concerned about the elective process, its adjustment \& control as in Brazil, } \\
\text { Chili supported the political structure of factions, and Mexico supported guaranteeing } \\
\text { minorities participation in the elections. }\end{array}$ \\
\hline Sovereignty of Law & $\begin{array}{l}\text { Brazil sought to found special courts for elections, and France reinforced the role of the } \\
\text { judge and courts at a high degree of independence, and development of judicial } \\
\text { institutions, systems of inquiry, transparency, corruption fighting, and decrease of crime } \\
\text { rate in the emirates. }\end{array}$ \\
\hline $\begin{array}{l}\text { Economic } \\
\text { Development }\end{array}$ & $\begin{array}{l}\text { There is a number of states obtained success in achieving averages of economic growth } \\
\text { shared in solving economic \& social problems (connected the growth process with } \\
\text { achieving social justice), that greatly reflected in the democratic conversion as states (of } \\
\text { Chili, Indonesia, South Korea and Malizia) }\end{array}$ \\
\hline Social & $\begin{array}{l}\text { Success of many states in concentration on importance of community care and } \\
\text { elimination of monopolistic procedure in policies of trade freedom and distribution of } \\
\text { all benefits of economic growth among different classes of the community by increase } \\
\text { of government expenditure size as in Brazil, south Africa \& Australia. }\end{array}$ \\
\hline Political will & $\begin{array}{l}\text { As in states of Morcco, Emirates \& Kuwait political will in reinforcing political } \\
\text { multitude \& inquiry. }\end{array}$ \\
\hline Popular Unanimity & $\begin{array}{l}\text { That appears as a result of case of instability and acceptance of a new roadmap, at all } \\
\text { aiming at transferring to the stage of democracy and certainty as Indonesia. }\end{array}$ \\
\hline $\begin{array}{l}\text { Respect of Human } \\
\text { Rights }\end{array}$ & $\begin{array}{l}\text { States of Kuwait, Emirates \&Jordancould increase levels of respecting human rights, } \\
\text { increased in states of China, Iraq and Syria. }\end{array}$ \\
\hline
\end{tabular}

\subsection{Secondly: Effect of Internal and External Determinants in the Democratic Trend in Jordan before the Year 2011}

The Jordanian political regime is viewed as one of the royal systems of the government "Parliamentary Royal Hereditary" ". It is nearer to the parliamentary regime, where the state is performed on three main authorities: (executive, legislative, and judicial) a little bit independent from each other, but they cooperate among each other. The Jordanian Political Regime is performed on mixing among the three authorities in accordance with the article (25)* from the constitution.

The executive authority in accordance with article (26) from the constitution is entrusted with the King, he holds it by his ministers in accordance with verdicts of the constitution. The King is the head of the state, he is preserved from every liability and responsibility ${ }^{14}$, he performs appointing the prime minister and accepts his

\footnotetext{
${ }^{12}$ Al-Majali Radwan (2014) The Effect of Trade Freedom in the Democratic conversion: Theoretical Study in the Internal \& External Factors, journal of Social Sciences, Kuwait University, vol. 43, No.3, p. 197.

${ }^{13}$ The first article of the Jordanian Constitution of 1952.

$\left.{ }^{*}\right)$ this article words that "the legislative authority is entrusted with the Council of nation and the King".

${ }^{14}$ Article (30) of the Jordanian Constitution in 1952
} 
resignation and appoints the ministers, disposes them and accepts their resignations due to the prime minister's attribution $^{15}$.

Jordan started trending towards democracy since the foundation of the Hashemite Kingdom of Jordan in 1946. With variant steps the effect of internal and external factors had the great part in the disablement the track of democracy in different historical stages, where the decade of fifties in the twentieth century witnessed a period of effectiveness of the factional system structure, that resulted in the first form of the parliamentary government in 1956, but the Israeli-Arab conflict and the case of regional instability at the period led to disablement of the parliamentary and factional structure and announcement of the martial law more than once continued till the year 1989, that the influence of the internal factor had (popular protests) as an effect of the economic crisis, which had been a result of the failure of confirmation policies and structural adaptation imposed by the international economic associations, on purpose of making a series of structural reforms led to more of defects in economy created an economic problem in the year $1989^{16}$, led to decline in the Jordan dinar price exchange. This thing pushed King Al-Hussein Bin Talal to response to the popular demands to discharge the government led by Zeid Al-Rifai', and cancel the martial law and work with the constitution of 1992 and call for parliamentary elections discharged the Eleventh Parliamentary Council in which the opposing political powers appeared represented greatly in the government through entering members of the Moslem Brotherhood Movement in the government of Mudar Badran in the period 1989-1991 ${ }^{17}$.

And after that period the influences of the Second Gulf War in 1990 and its effects on Jordan, the matter that led to start the stage of national convention in 1991, and issuing the political factions lawin 1991, then came the start of the Peace Process in the Middle East affecting the Jordanian internal political domain, through the rise of political changes commenced by internal rejection of the Peace Process with Israel in 1994, and changing the elective system towards the one vote in 1993, that restricted the appearance of political factions, the thing that led to Moslem Brotherhood boycott the parliamentary elections ${ }^{18}$, then another economic crisis rose in Jordan which had its reflections on the political stability. It started in 1996 as a result of the government action of releasing support from prices of bread, fodders and the rise of prices of other foodstuffs. Protests and demonstrations in the Southern governorates of Jordan appeared, the matter that pushed the King to interfere once again to response to the popular demands, and start the stage of dialogue with the political factions, but it did not work, because of the rise of the crisis in the relationship between the state and the citizen.

Influence of the second Palestinian Rise (Intifada) in the year 2000, and incidents of September 11, 2001 formed a great role in tumbling the political reforms in Jordan as a result of fluctuation of the political process in Jordan between the retreat and effectiveness, where the period extended (2000-2002) had witnessed a period of political vacancy because of absence of the parliament, the matter that the government exploited by issuing more than(250)temporary laws to reinforce the different reform processes, till the political effectiveness returned with the return of the Fourteenth parliamentary council in the year 2003. Jordan after that period had been affected be the American occupation of Iraq in 2003, and increase of Iraqi refuge to Jordan, the thing that had the effect on economic conditions.

That period witnessed a true problematic in the nature of relationship between the legislative authority and the government, had been expressed with evident domination of the executive authority on actions of the Fourteenth Council of the parliament 2003, and the Fifteenth Council of the Parliament 2007, the matter that made it lose the effectiveness in deeds of control, inquiry and legislation. Intended criticisms increased from factions, political powers, public opinion and media means for the political performance of the council, the thing that pushed King to dissolve the parliament council in the year 2009 before two years of its termination ${ }^{19}$.

From here it is evident that factors of pushing towards democracy are affected with the internal and external factors, so Jordan begins to increase the track of trending towards democracy together with increasing the effects of the internal environment, that increases pressures as a result of rising regional conditions in stable or outcomes of the failure of the economic correction programmes and problems of Jordan economy and its

\footnotetext{
15 The article (35) of the Jordanian Constitution in 1952.

${ }^{16}$ Muhafizah, Ali 2001. Restricted Democracy, Case of Jordan 1989-1999, center for studies of Arab Units, Beirut, pp. 100-119.

${ }^{17}$ Ellen hust. Okar, (2005) "Structuring conflict in Arab World: Incumbents, Opponents and Institution “, Cambridge University Press. Page 103.

${ }^{18}$ The Arab Strategic Report 2004-2005, center for political \& Strategic Studies in Al-Ahram, Cairo, July 2005,p. 283 \&293.

19 Al-Majali Radwan (2013). Protest Movements on Jordan: Between Demands and Response, Arab Journal for Political Sciences, Center for Arab Unity Studies, Beirut, No. 38, p. 13.
} 
reflections on the citizen. The size of the Jordan political regime response to democratic trends are affected with a group of internal and external factors, and they can be illustrated in the table 2 .

Table 2. Effective factors in the trend towards democracy in Jordan ${ }^{20}$

\begin{tabular}{ll}
\hline Internal Determinant & External Determinant \\
\hline Economic System: limitness of economic provisions, & \\
Privatization, Budget Shortage, Balance of Trade Shortage, & The Palestinian Problem and state of Regional \\
Inflation, Increase of External Indebtedness, Increase of & $\begin{array}{l}\text { instability, terrorism and Extremism. } \\
\text { Dependence on loans and external aids, Increase of Taxes\& }\end{array}$ \\
fees, Disappearance of the Middle Class. & \\
\hline Social System: Decrease of life level and Increase of Poverty & \\
and Unemployment, Spreading of Corruption, Mediation and Influence of Donating Parties, and the \\
Patronage,Increase of Crime, Problems and Social Violence, International Economic Associations. \\
Tribalism, Regionalism and directionalism.
\end{tabular}

Political Regime (System): legitimacy of regime and the government and the Nature of the Political Will and its Trends, Nature of Legislations and the organizing Political Laws of the Democratic work, And Nature of the Relationship Globalization and the Worldly Economic Crises between Both Legislative and Executive authorities.

Educational System: Weakness of Scientific Research, decrease of Education Level, Weakness of Arabic language, non-appropriateness of Educational outputs with Labour Market, Problems in Educational and Teaching Curriculums.

Compulsory Emigration of the Palestinian Refugees, the years 1948 and 1967. Emergency Emigration succeeding the second Gulf Crisis, 1991, and the American Occupation of Iraq 2003, and the Crisis of the Syrian Refuge 2011.

In spite of the steps taken by Jordan to trend towards democracy through doing a series of political and economic reforms at the period before the Arab Spring, but it possible to raise the most important effective internal challenges in the retreat towards democracy in the following points:

1) Weakness of the political factions role and the other institutions of the civil community in the political life.

2) The negative influences of the tribal system in the factional and electional system.

3) Increase of the gap in the relationship between the citizen and the government.

4) Weakness of the legislative authority performance and domination of the executive authority upon it.

5) Effects of the negative economic and social problems in the political structure.

6) Weakness of the political culture and the political breeding.

7) Weakness of opposition and increase of influence of the political elites in the political life.

\subsection{Thirdly: Influence of the Arab Spring on Jordan}

Appearance of the Arab Spring at the endings of the year 2010 and the beginning of the year 2011 formed the start of change wave in the Arab region, and increase of the state of regional instability influences in territories of (Tunisia, Lybia, Egypt, Syria, Yemen and Iraq), the matter that together formed an effect on the Arab setting, and increase of the international and regional interventions size, the thing that led to changing the political and economic reality of the region, and the rise of different issues , from them issues of: the democratic conversion, the political stability, and terrorism and extremism.

\footnotetext{
${ }^{20}$ Al-Sawadhah, Aghadeer (2006). Effect of Regional Changes on Political Stability in Jordan (2011-2016), unpublished master degree dissertation, Dept. of political Science Mu’ta University,2016, pp.34-387.
} 
Perhaps some people believed that the stage of the Arab Spring will form a stage for beginning a democratic conversion in some Arab states, but on the contrary of that, it had been proved that the success of the democratic state model needs other conditions, in spite of that one of the main causes to the burst of the case of anger in the tracks of the revolution in the states of the Arab Spring was the economic factor as a result of failure of policies of trade release and increase of economic problems sharpness: aggravation of poverty, decrease of living level, disappearance of the middle class, increase of unemployment, and increase of development acquirement at a certain class in the community on the expense of other classes ${ }^{21}$.

But for Jordan it had been affected with the wave of the Arab Spring through the period extended(2011-2017) and at variant degrees and on the different levels (political, economic, security, and social):

At the economic level: the state of instability in the states of the Arab Spring it shared in the retreat of the Jordanian economic growth, and increase of the economic problems' sharpness: aggravation of the external indebtedness to more than 31 milliard in 2016, and increase of budget shortage in the year 2015(\%51) compared with the previous years, in addition to increase of the size of unemployment, increase of inflation, rise of the rate of taxes and fees, and shortage of the balance trade (look the table 3 ).

Table 3. The different economic indicators (2000-2015) by Percentages ${ }^{22}$

\begin{tabular}{|c|c|c|c|c|c|c|c|c|c|c|c|c|c|}
\hline years & ষ্ণ & 兑 & ఠิ & $\hat{\overbrace{}}$ & 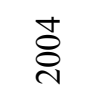 & ڤ̊̀̊ & 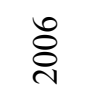 & ڤ્ণ & $\stackrel{\infty}{0}$ & $\overline{\bar{i}}$ & $\stackrel{m}{\stackrel{n}{2}}$ & $\underset{⿱}{\stackrel{\Delta}{i}}$ & $\stackrel{n}{2}$ \\
\hline $\begin{array}{l}\text { Average of growth in } \\
\text { gross local outcome }\end{array}$ & 4.2 & 5.3 & 4.2 & 3.2 & 8.5 & 7.2 & 6.4 & 5.9 & 6 & 5.5 & 2.8 & 3.1 & 2.6 \\
\hline Unemployment Rate & 13.7 & 14.7 & 15.3 & 14.5 & 14.7 & 14.8 & 13.9 & 13 & 12.7 & 12 & 11 & 12.3 & 13.6 \\
\hline Inflation Rate & 0.7 & 1.8 & 1.8 & 2.3 & 3.4 & 3.5 & 6.3 & 7.5 & 15 & 13 & 5.6 & 3.2 & 2.3 \\
\hline $\begin{array}{l}\text { Rate of shortage in } \\
\text { Balance of Trade }\end{array}$ & 31 & 28 & 24 & 26 & 37.7 & 48.7 & 44 & 20 & 24 & 35 & 35.9 & 39.9 & 52.7 \\
\hline $\begin{array}{c}\text { Rate of shortage of } \\
\text { General Budget }\end{array}$ & 3.4 & 3.5 & 3.2 & 2.7 & 2.8 & 5.3 & 4.4 & 4.5 & 5 & 7 & 5.4 & 6.9 & 2.5 \\
\hline
\end{tabular}

It is evident from the previous table that the period of the Arab Spring had led to increase of Jordan economy problems resulting from the retreat of economic growth, retreat of trade among states of the region, decrease of returns of hotel and tourist sector, and rise of the Syrian refuge problem that started affecting the Jordan economic system negatively ${ }^{23}$.

At the security level: the Arab Spring led in its beginnings retreat of security perception indicators in Jordan at different stage, weakness of the state dignity and sovereignty of the law-especially in finding radical solutions to societal violence problems, and spread of the crime phenomenon. This matter initiated to some people that the application of stability and security equation resembles popular choices and demands, so imposing the first one is an instrument weakened that limits of political and social stability in Jordan ${ }^{24}$.

Corresponding to that terrorism and extremism formed the most prominent affecting factors in the period of the Arab Spring and aiming Jordan and challenging its security by extremist groups and organizations pushed it to increase security perception and international and regional coordination through participation in the international alliance against the terrorist organization of Da'ish; and the Arab Alliance in Yemen, and concluding numerous security and military treaties with numerous states in the domain of fighting terrorism and extremism.

At the Social level: The Arab Spring and the issue of the Syrian Refuge in Jordan shared in increasing the social

\footnotetext{
${ }^{21}$ Al-Jorshi, Salah Addin (2013). Arab Revolutions. A project defected from inside it Journal of Arab Affairs, No. 156, Cairo, League of Arab State, p. 67.

${ }^{22}$ Al-Majali Radwan (2016). Readings in the Jordanian politics, summaries of research in Jordanian politics, Dept. of political Sciences, Mu'ta University, p. 26.

${ }^{23} \mathrm{Al}$-Sawadhah (2016), Ibid, pp. 57-58.

${ }^{24}$ Ottaway, Marina and Hamzaway, Omer, "protest Movements and political change in the Arab World" policy outlook, Carnegie Endowment for International Peace, Middle East Office, Beirut, 28 January 2011, page 4.
} 
problems, where the sharpness of social congestion increased, poverty and unemployment, corruption, and crime in creased and anesthetics spread, social problems, societal violence, and problem of the Jordanian family...etc.

At the political level: The Arab Spring led to increasing the role and concern of the politicalleadership - as one of the indicators of democratic trend - in the haste of response to the demands of the popular motionand variant degrees and positively more than it was before the Arab Spring. These demands had been concentrated on the following:

- The economic reform through: treating misshaping's and disorders in the economic system, (treating both problems of unemployment and poverty, decrease of prices, particularly, especially oil derivations, treating shortage of budget and external indebtedness, and reviewing the economic policies (Privatization and investments) $)^{25}$.

- Political reform through: lightening the imposed restrictions on expression freedom, and political participation, reinforcingthe roleof the civil community institutions in the political life and amendment of the political laws, restricting the political work (such as law of political factions, law of election for the one vote, and press and publication law) and do fair parliamentary elections and uplift the security grip from the political life. Reforming the system of the government (regime) through: the call for performing a constitutional monarchy by founding an elected parliamentary government holding public custodianship, and doing constitutional amendments reinforce the peoples role in the government and guarantees his rights. And in reinforcing indicators of the good government through: fighting corruption and call for accounting corruptors, inquiry and transparency ${ }^{26}$.

Therefore, we find that what characterizes the protest movements in Jordan that the roof of their demands did not overstep the limits of constitutional monarchy ${ }^{27}$.

And the response had appeared through (the constitutional and legislative amendments, increase of political participation, and increase of national dialogue sessions...etc.).

\subsection{Fourthly: Steps of Democratic Trend in Jordan during the Period of the Arab Spring}

The political will appeared as one of the effective internal determinants in motivating the democratic trend in Jordan in spite of rising the effective internal and external challenges in weakening that, the most important stepsof democratic trend and politicalreform in Jordan can be summarized in the following:

1) Increase the concentration of the Jordanian political address at all local and international occasions on the importance of achieving the indicators of the democratic conversion (parliamentary governments, activating the political factions, reinforcement of the political participation and reinforcement of political freedoms).

2) Issuing the Seven Royal Discussing Papers (2012-2017): they are a group of papers that represent King Abdulla, the Second Ibnel Hussein's vision in achieving a group of the politicalprogrammes, that aim at reinforcing the track of the political reform in Jordan, and the political development, organizing the relationship between the citizen and the state and bringing out his rights and duties frankly and clearly, and with what reinforces his ability to practice a political role in the community. It covered the main titles of the Seven Discussing papers, the following: the first paper entitled: our track towards creating the renewed democracy. Meanwhile the second discussing paper bore the title: developing our democratic system to serve all Jordanian. Meanwhile the Third Discussing Paper showed the subject: Roles are waiting us for the success of our renewed democracy. But the Fourth Discussing Paper had come entitled. Towards Democratic Empowerment and Effective Citizenship. And the Fifth Discussing Paper discussed the title: Deepening the Democratic Conversion:objectives, Accomplishments and the political conventions.But the Sixth Discussing Paper entitled: Sovereignty of the law is the Basis of the Civil State. But the Seventh Discussing Paper entitled: Building our Human Abilities and Developing the Educational Process is the Core of the Nation's Renaissance ${ }^{28}$.

3) Forming the committee of the national dialogue to discuss subjects of the political and economic reforms.

\footnotetext{
${ }^{25}$ Sehwedler, Jillian, "the politics of protest in Jordan”, Foreign Policy Research Institue, Footnotes, The Newsletter of FPRI's Wachman, Philadelphia Feb. 2012,P.3.

${ }^{26}$ It is meant "the King possesses and do not govern" means does not interfere in forming the governments, they are formed by election. It is applied Al-Maghreb lately in elections.

${ }^{27}$ Al Raggad, Nayef (2017) . the Political Reform in Light of the Royal Discussing Papers (2011-2017),Unpublished Doctorate Degree Dissertation, Dep. Of Political Science, Mu'ta University, p. 8.

${ }^{28}$ Al- Masalhah Mohammad, (2015). Constitutional Amendments in Jordan: The Political \& Legal Dimensions, Dar Wael, Amman, Jordan, p. 8 .
} 
4) Entrusting a special royal committee by the King to do amendments on the Jordanian Constitution of the year 1952, that did a review of the Jordanian constitution texts, where it tackled (42) articles of the constitution, covered reinforcing competences of the legislative authority, fortification of the Parliament from dissolution, creating a constitutional court, and cancelling the higher council for explanation of the constitution and presenting the ministers for trial at the normal judicature, and remained the King's competences in appointing prime ministers, but restricted his competence in the dissolution of the Parliament.

5) Haste in changing the Jordanian governments through the wave of protests at an average of (4) governmentsduring both years of 2011-2012, to uproot states of the political, economic and prevailing social congestion.

6) Increasing dialogue sessions and meetings in between the government and the Islamic Group.

7) Confirmation of Teachers' union Law No. (14) for the year 2011.

8) Formation of fairness system on December $8^{\text {th }} .2012$, that concerns about reviewing the legislation and studying the reality of gathering the controlling parties, diagnosing problems the face them and be aware of places of defects and weakness, propose recommendations, that strengthen and correcting the track of these parties' work in fighting corruption and reinforcing cooperation in between them deducing better standards of balanced institutional work, and perhaps guarantees stability of justice climate, and inquiry due to performance achieving the public interest.

9) Forming a national committee in the year 2016 headed by the former prime minister Zeid Al-Rifai', for the sake of developing the judicial Institution and reinforcing the sovereignty of the law, which submitted its report to his majesty King Abdullah, the second in February 2017, about how to raise the Judicial Institution and reinforce the sovereignty of the law.

10) Confirmation of a group of political laws, organizing the political life (law of Decentralization (N0. 49) of the year 2015, Law of Political factions No. (39) of the year 2015, the Amending Law of Election Law of the year 2012, and the Election Law No. (6) of the year 2016).

11) Supervision and control of the Independent Corporation for Election on the Legislative, Municipal Elections and Elections of the Decentralization.

12) Doing the Parliamentary and Municipal Elections in the year 2013. The Parliamentary Elections of the year 2016, and the Municipal and the Decentralization for the Local Councils of the Governorates for the year 2017.

From here it is evident the existence of true steps in trending towards democracy in Jordan with the motivation of the political will for the Jordanian decision-maker in the period of the Arab Spring in the shadow of increasing the internal and external environment challenges, but there are difficulties still exist in the Jordanian democratic structure connected in the political, economic and social structures are still affect transferring the indicators of trending to democracy into advanced steps of conversion to democracy.

\section{The Conclusion}

The study deduced a group of results can be summarized in the following:

1) Correctness of hypothesis of study: where it proved that the Arab Spring is one of the external factors affecting the democratic trend in Jordan positively and negatively, where factors of regional instability and the wave of demonstrations and protests formed an affecting side in increasing the response of the political authority with the popular demands during the period of (2011-2017). In time the economic, social and security precariousness's formed an affecting factor on the political, economic and social structures, that led to vising problems and challenges caused hindering the democratic trends in Jordan.

2) The steps of the democratic trend in Jordan through doing a series of constitutional and legislative reforms in the law organizing the political life, and forming committees of national dialogue, and motivating machineries of fairness and development of judicature.

3) Difficulties related with the extent of harmony of political laws (election and political factions) rose with the political and social structures inside the Jordanian regime (political system).

4) Existence of structural problems, economic and social from true challenge in reinforcing the democratic trend in Jordan.

5) The study assured that the democratic conversion does not depend only on indicators: amending the constitution, laws and political participation, but depend on other important indicators: political breeding, 
political culture, dialogue and national agreement, independence and control of legislative authority, reinforcement of law sovereignty, political freedoms and effectiveness of the civil community.

The study recommended with the following points:

1) Significance of achieving the political stability through achieving stability in the political, economic, and social structures, and exploiting this stability with achieving balance between the political and popular will in reinforcing the democratic trend.

2) Necessity of reinforcing effectiveness and indicators of the democratic conversion: respect of human rights, effectiveness of the civil community institution, economic development, political and social stability and the democratic culture and practice.

3) Assuring the reach to parliamentary governments and the concept of the parliamentary system, appears through reinforcing the role of political factions and their effectiveness's, and the role of the civil community institutions.

\section{References}

Abu A'mood, M. (2009). The Democratic conversion and its Difficulties in the Arab Countries. Journal of Democracy.

Ahmad, I. (2016). Democracy and Democratic Conversion. Egyptian Institute for thepolitical \& strategicstudies, Cairo.

Al-Jorshi, S. I. (2013). The Arab Revolutions: a defect project from its inside. Journal of Arab Affairs, (156).

Al-Majali, R. (2013). The Protest Movements in Jordan: between Demands and Response. The Arab Journal for Political Sciences, (38).

Al-Majali, R. (2014). Effect of Trade Freedom in the Democratic conversion: A Theoretical Study in the Internal and External Factors. A Journal of Sociology, Kuwait University, 43(3).

Al-Majali, R. (2015). The political and Economic Reform in Jordan between Theory and Application. Journal of Education, Al-Azhar University, Cairo, (162).

Al-Majali, R. (2016). Readings in the Jordanian Politics, Summaries of a Subject Study in the Jordanian Politics. Department of Political Science, Mu'tah University.

Al-Masalhah, M. (2005). The Constitutional Amendments in Jordan: the Political and Legal Dimensions. Dar Wael, Amman, Jordan.

Al-Munofi, K. (1987). Fundamentals of comparative Political Systems. Rbeia'n, Kuwait.

Al-Raggad, N. (2007). The Political Reform in Light of the Royal Discussing Papers (2011-2017), Unpublished Doctorate Degree Dissertation, Department of Political Science, Mu'tah University.

Al-Salek, D. (2008). The Democratic Practice is an Introduction to Arabic Everlasting Development. Journal of the Arabic Future, (356).

Al-Sawadhah, A. (2016). Effect of Regional Changes on the Political Stability in Jordan (2011-2016), Unpublished Master Degree Dissertation, Department of Political science, in Mu'tah University, 2016.

Article (30) from the Jordanian Constitution of the year 1952.

Article (35) from the Jordanian Constitution of the year 1952.

Ellen Lust, O. (2005). Structuring Conflict in Arab World: Incumbents, Opponents and Institutions. Cambridge University Press. https://doi.org/10.1017/CBO9780511491009

Ibrahim, H. (2013). Democratic Transference in the Arab World, Dawha, Al-Jazeera Center for studies, February $14^{\text {th }}$.

Ka'sees, K. (2014). The Arab Spring between Revolution and Disorder. Journal of the Arabic Future, (421).

Muhafzah, A. (2001). Restricted Democracy, Case of Jordan: 1989-1999. Center for Studies of Arab Unity, Beirut.

Nafa', H. (2007). Principles of Politics, International Shorooq Library, Cairo.

Ottaway, M., \& Omer, H. (2011). Protest Movements and Political Change in the Arab World. Policy outlook, Carnegie Endowment for International Peace. Middle East Office, Beirut.

Schwedler, J. (2012). The Politics of Protest in Jordan. Foreign Policy Institute, Footnotes. The Newsletter of 
FPRI'S Watchman center, Philadelphia.

The Arab Strategic Report 2004-2005, Center for Political and strategies studies in Al-Ahram, Cairo, July, 2005.

The first article from the Jordanian Constitution 1952.

\section{Copyrights}

Copyright for this article is retained by the author(s), with first publication rights granted to the journal.

This is an open-access article distributed under the terms and conditions of the Creative Commons Attribution license (http://creativecommons.org/licenses/by/4.0/). 